\title{
Comparison of lgE induction in mice by pollens from three pine tree species
}

\author{
Seo-Yoong Kim ${ }^{1}$ In-Bo Oh ${ }^{2}$ and Kee-Ryong Choi ${ }^{\text {* }}$ (D)
}

\begin{abstract}
Background: Over the years, pine pollens have been excluded as an allergen due to its relatively large size, low protein content, and waxy hydrophobic layer, despite their abundance. However, recent studies suggest the possibilities of pine pollens being allergens, and it has been reported that allergy symptoms were highly prevalent in areas with considerably large pine forests and high possibility of exposure to the pollen. Therefore, we conducted a comparative analysis of the allergenicities of the pollens from the dominant species of Korean pines, red pine (Pinus densiflora), black pine (Pinus thunbergii), and pitch pine (Pinus rigida), in mice.

Methods: The protein composition of the pollens from the three pine species was compared via sodium dodecyl sulfate polyacrylamide gel electrophoresis (SDS-PAGE). The pine pollens and proteins extracted from the pollens were introduced to BALB/C mice by nasal inhalation and application to exposed skin and the lgE produced by the mice were extracted from blood and analyzed via ELISA.

Results: SDS-PAGE showed differing protein compositions of the pollens of the three pine species. Analysis of blood IgE compositions showed a similar amount of IgE produced when pollens were applied to skin. In contrast, when mice inhaled the pollens, P. densiflora was shown to induce significantly more IgE production than those of the other two species.

Conclusions: The experimental results demonstrate that the pollens of all three South Korean pine species induce IgE production, and this production was more pronounced when the pollens were inhaled than when they were applied to the skin. Of the three species, the pollen of $P$. densiflora was found to induce the highest level of lgE production.
\end{abstract}

Keywords: Pollinosis, Allergen, IgE, Red pine, Black pine, Pitch pine

\section{Background}

Several characteristics of pine pollen, such as its relatively large size $(45-65 \mu \mathrm{m})$, low protein content, and waxy hydrophobic layer, have led researchers to exclude it as a possible cause of allergic reactions, despite its abundance (Howlett et al. 1981; Pettyjohn and Levetin 1997). It has even been used as a negative control in inhalation challenge tests (Frølund et al. 1986). However, some studies have suggested the possibility of pine pollens being allergens (Walker 1921; Rowe 1939; Newmark and Itkin 1967; Harris and German 1985; Cornford et al. 1988; Kalliel and Settipane 1988; Cornford et al. 1990). In addition, significantly high rates of allergy

\footnotetext{
*Correspondence: pollen@ulsan.ac.kr

'Department of Biological Science, University of Ulsan, Ulsan 44610, South Korea

Full list of author information is available at the end of the article
}

symptoms have been reported in areas with considerably large pine forests and, hence, a high possibility of exposure to pine pollen (Farnham and Vaida 1982; Farnham 1988; Fountain and Cornford 1991; Freeman 1993; Gastaminza et al. 2009). In South Korea, it has been reported that $7.31 \%$ of asthmatic patients and $16.9 \%$ of allergic coryza and conjunctivitis patients test positive to pine pollen as an allergen (Hong 2015).

There are over 90 species belonging to the Pinus genus worldwide (Lawrence 1951). Korean forests are composed of $40.5 \%$ coniferous forests, $27 \%$ broadleaf forests, and $29.3 \%$ mixed stand forests. These coniferous forests are primarily dominated by pines, including Pinus densiflora (56.1\%), Pinus rigida (15\%), Pinus koraiensis (8.3\%), Cryptomeria japonica, and Chamaecyparis obtusa (3.4\%) (Korean Forest Service 2011). It has also been 
determined that among the airborne pollens in South Korea, pine pollen disperses for the longest period at the highest abundance (Oh et al. 2000; Choi et al. 2011; Jung and Choi 2013; Choi et al. 2014). Studies have reported differences in the antigenicities of the pollens of various allergenic plants. Therefore, detailed information regarding the antigenicity of each species is needed (Calenoff et al. 1990; Park et al. 1999; Shahali et al. 2007; Cox et al. $2009,2011)$. The purpose of this study was to investigate the antigenicity of pine pollen, especially $P$. densiflora, $P$. thunbergii, and $P$. rigida pollen, derived from Korean pine plants. To analyze the protein allergens of these pollens, three types of proteins were compared by SDS-PAGE. We also observed the changes in IgE expression induced by pine pollens in mice after nasal inhalation and skin application (Tamura et al. 1986; Tordesillas et al. 2015).

\section{Methods}

Collection of pine pollens from $P$. densiflora, $P$. thunbergii, and $P$. rigida and preparation of pollen antigens

The pine pollens used in this study were collected from $P$. rigida, $P$. densiflora, and $P$. thunbergii samples from the University of Ulsan (St. A), Mt. Munsu (St. B), Guyu-dong (St. C), and Yeonam-dong (St. D), South Korea, respectively from April to May, 2014 (Fig. 1).

Male flowers were collected and dried in the shade for 7 days. From these, pollen was extracted through a sieve with a pore size of $150 \mu \mathrm{m}$. Next, $5 \mathrm{~g}$ of each pollen sample was added to 5 volumes of ethyl ether $(w / v 1: 5)$, stirred twice every $12 \mathrm{~h}$ at $4{ }^{\circ} \mathrm{C}$, and air-dried for $12 \mathrm{~h}$ to completely remove ethyl ether. The completely defatted sample was then added to phosphate-buffered saline (PBS; pH 7.8) in a $w / v$ ratio of $1: 5$ and stirred for $24 \mathrm{~h}$ at $4{ }^{\circ} \mathrm{C}$, after which it was centrifuged for $30 \mathrm{~min}$ at $21,000 \mathrm{~g}$ at $4{ }^{\circ} \mathrm{C}$. The protein-containing supernatant was extracted and dialyzed by adding the sample to a dialysis tube and placing the tube in distilled water at $4{ }^{\circ} \mathrm{C}$ for $48 \mathrm{~h}$, during which the water was changed 2-3 times. Then, the samples were filtered with a $0.45-\mu \mathrm{m}$ Millipore filter and stored at $-20{ }^{\circ} \mathrm{C}$. Using the Thermo Scientific Pierce bicinchoninic acid (BCA) Protein Assay, the presence of proteins in the sample was confirmed by a change in color, and the amount of protein was quantified and standardized based on the absorbance of each sample.

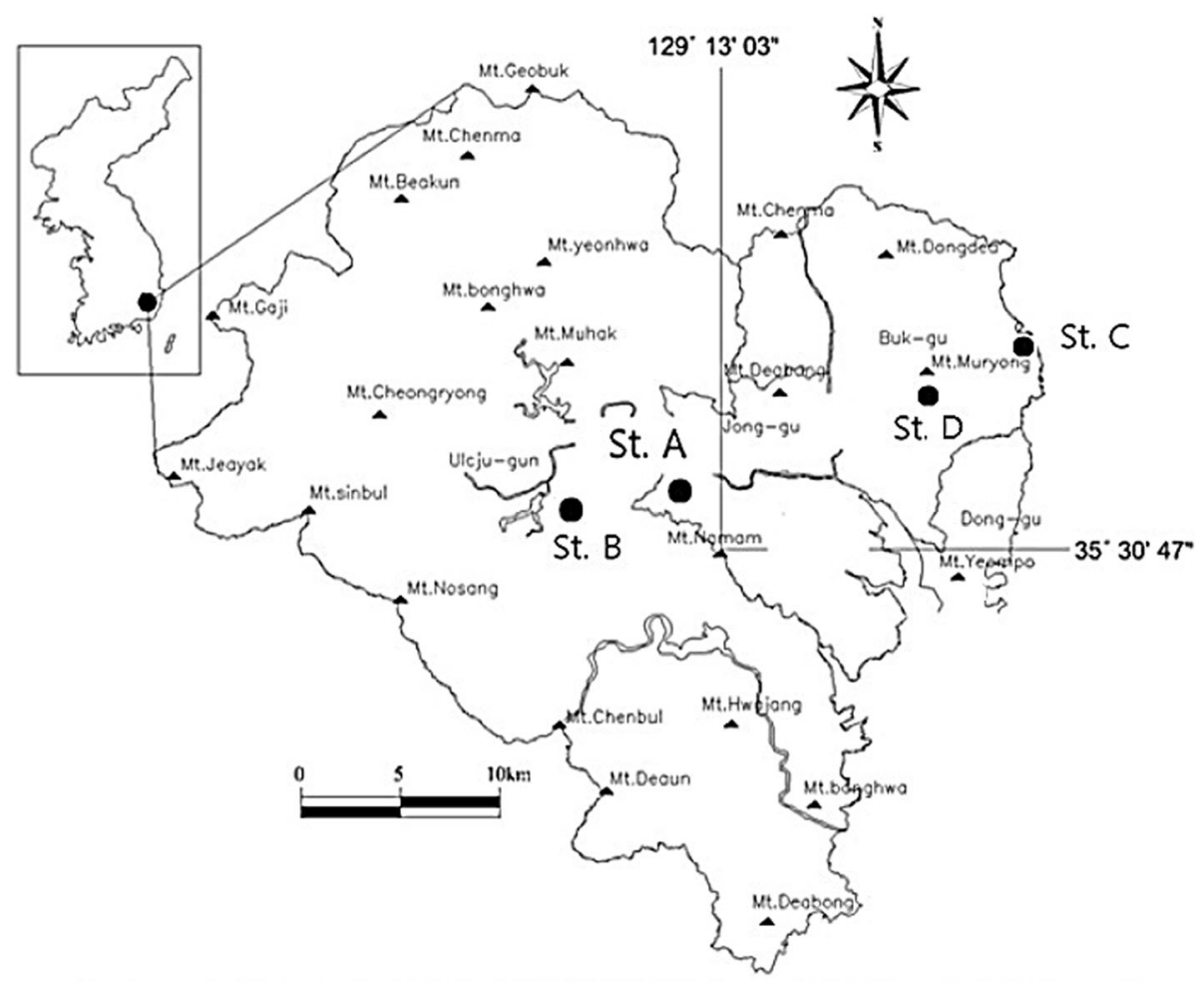

St. A : University of Ulsan - P. rigida

St. B : Mt. Munsu - $P$. densiflora

St. C : Guyu-dong, Ulsan - P. thunbergii

St. D : Yeonam-dong, Ulsan - $P$. thunbergii

Fig. 1 The collection sites for pollens of $P$. densiflora, $P$. thunbergii, and P. rigida 


\section{SDS-PAGE of pine pollen antigens}

Polyacrylamide gels were made at 10\%, 15\% (separating gels), and 5\% (stacking gels), and the protein samples were mixed with SDS gel-loading buffer $(50 \mathrm{mM}$ Tris.Cl, $2 \%$ SDS, $0.1 \%$ bromophenol blue, $10 \%$ glycerol, and $1 \%$ $\beta$-mercaptoethanol) and boiled for $3 \mathrm{~min}$ to prepare for electrophoresis. Standard size markers and the samples were added to the wells and run at $80 \mathrm{~V}$ for $3 \mathrm{~h}$ in a Tris-glycine electrophoresis buffer system ( $25 \mathrm{mM}$ Tris, $250 \mathrm{mM}$ glycine, and $0.1 \%$ SDS). Then, the gel was stained in a staining solution $(0.25 \%$ Coomassie Brilliant Blue R250 and 10\% glacial acetic acid in methanol: $\mathrm{H}_{2} \mathrm{O}$ 1:1 $\mathrm{v} / \mathrm{v}$ ) and destained with a destaining solution (methanol: glacial acetic acid: $\mathrm{H}_{2} \mathrm{O}$ 3:1:6) that was changed 3 times. SDS-PAGE was used to conduct a comparative analysis of the proteins of the pine pollens of $P$. densiflora, $P$. thunbergii, and $P$. rigida. Gels of different concentrations (5, 10, and $15 \%$ ) were used to broaden the size range of the proteins that could be analyzed.

\section{Mice}

Female Balb/c mice aged 7 weeks were purchased from the Dae-Han Bio Link Co. Ltd. They were maintained under specific pathogen-free (SPF) conditions in the animal facility of the University of Ulsan and were used at 8-10 weeks.

\section{Detection of changes in IgE expression induced by pine pollens in mice}

In order to assess the induction of IgE expression in a mouse system by pine pollens, the procedure described in Fig. 2 was carried out. That is, for nasal inhalation tests, $0.05 \mathrm{~g}$ of pine pollen from $P$. densiflora, $P$. thunbergii, or $P$. rigida was added to $1 \mathrm{~mL}$ of sterilized distilled water and mixed by vortexing. This produced a homogeneous mixture of a $0.05 \mathrm{~g} / \mathrm{mL}$ solution; $25 \mu \mathrm{L}$ $(1.25 \mathrm{~g})$ was injected directly into the nasal cavity of each mouse $(n=5)$ daily for 15 days. Another method

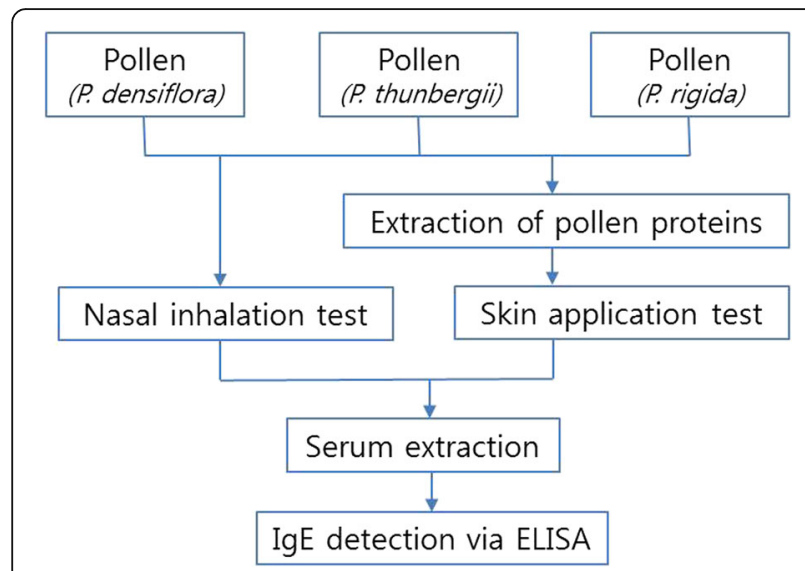

Fig. 2 Pine pollen sensitivity test procedure

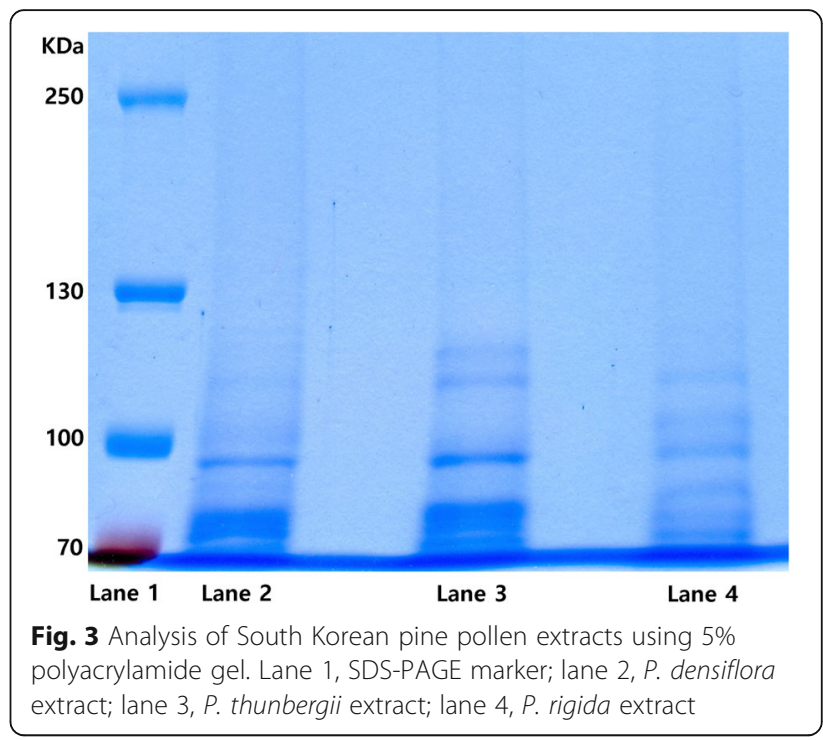

involved a skin test during which each anesthetized mouse had its back fur removed with clippers. Then, $100 \mu \mathrm{L}$ of pine pollen proteins from $P$. densiflora, $P$. thunbergii, or $P$. rigida was applied to the skin daily for 15 days. In the control group, $25 \mu \mathrm{L}$ of sterilized distilled water was injected into the nasal cavity of each mouse once daily for 15 days. On days 5, 10, and 15 after introduction of pine pollens, capillary tubes were used to extract blood from the capillary vessels of the eyes of mice in the control group, nasal inhalation test group, and skin test group. The blood samples were centrifuged at $800 \mathrm{~g}$ for $15 \mathrm{~min}$, and the supernatant was extracted to

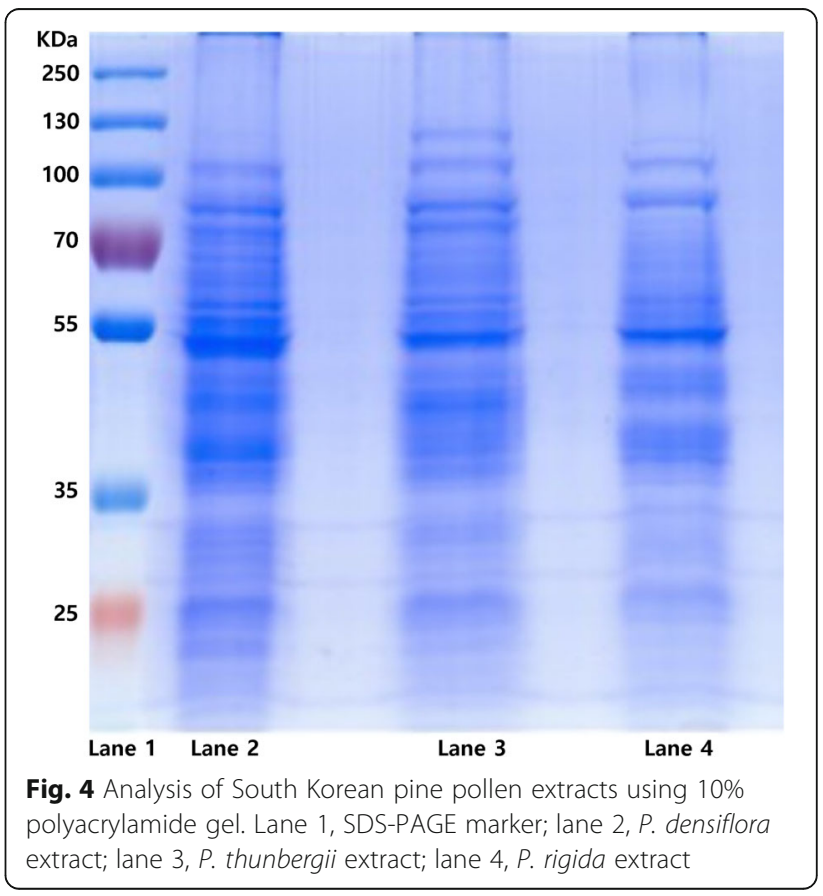




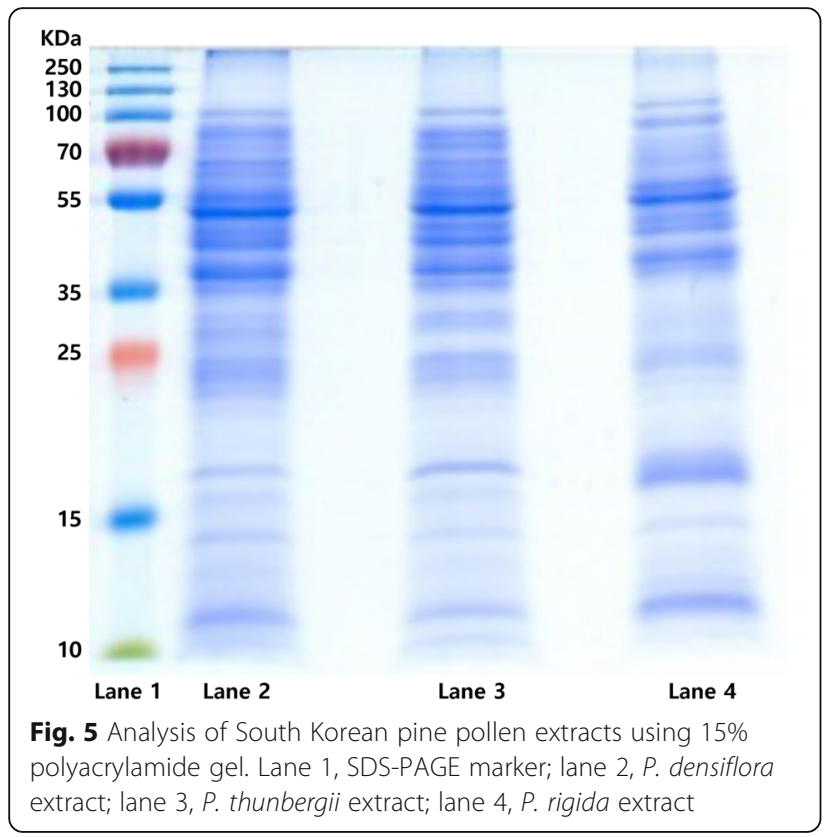

isolate serum, which was stored at $-20{ }^{\circ} \mathrm{C}$. A Mouse $\operatorname{IgE}$ ELISA kit (ebioscience mouse IgE ELISA Ready-SET-Go) was used to detect changes in IgE composition in blood serum samples of each group. A 96-well microplate was coated with IgE-capture antibody $(\mathrm{Ab})$ and incubated at $4{ }^{\circ} \mathrm{C}$ for $18 \mathrm{~h}$. To each well, $200 \mu \mathrm{L}$ of PBS-T (Tween 20, $0.05 \%$ ) was added and removed three times for washing. Then, $100 \mu \mathrm{L}$ of $2 \%$ bovine serum albumin (BSA) was added to each well and incubated at $20^{\circ} \mathrm{C}$ for $2 \mathrm{~h}$ to prevent unspecific binding. After washing each well three times with $200 \mu \mathrm{L}$ PBS-T, $50 \mu \mathrm{L}$ uniformly diluted mouse serum was added to each well and incubated for $2 \mathrm{~h}$. After washing each well three times with $200 \mu \mathrm{L}$ PBS-T,
IgE-detection $\mathrm{Ab}$ was added and incubated at $20{ }^{\circ} \mathrm{C}$ for $1 \mathrm{~h}$. After washing each well three times with $200 \mu \mathrm{L}$ PBS-T, horseradish peroxidase-bound secondary $\mathrm{Ab}$ was added and incubated at $20{ }^{\circ} \mathrm{C}$ for $30 \mathrm{~min}$. After washing each well three times with $200 \mu \mathrm{L}$ PBS-T, $100 \mu \mathrm{L}$ of a substrate for horseradish peroxidase, TMB (3, $3^{\prime}, 5,5^{\prime}$-tetramethylbenzidine), was added per well to induce a color change. Then, $100 \mu \mathrm{L}$ of $0.16 \mathrm{M}$ sulfuric acid stop solution was added to each well to stop the color change, and the absorbance was read at $450 \mathrm{~nm}$ using a microplate reader.

\section{Results and discussion}

\section{Analysis of pine pollen protein}

After 5\% SDS-PAGE, analysis of protein bands above $70 \mathrm{kDa}$ showed different band patterns at approximately 80 and $120 \mathrm{kDa}$ for $P$. densiflora, $P$. thunbergii, and $P$. rigida (Fig. 3). Next, 10\% SDS-PAGE was run to analyze proteins of 35-70 kDa. Even though an exact comparison of the protein bands of the pine species was difficult owing to the large number of proteins in this size range, it was clear that $P$. densiflora, $P$. thunbergii, and $P$. rigida all showed similar band patterns (Fig. 4). Finally, 15\% SDS-PAGE was run to analyze proteins under $35 \mathrm{kDa}$. The pollens from the three species showed different band patterns at approximately 30 and $17 \mathrm{kDa}$ (Fig. 5). According to previous data, the major antigens in pine pollen are of 42 and 6-8 $\mathrm{kDa}$ (Weber 2005). In addition, in the case of Pinus radiata, it has been reported that the main allergens are of $140,85,70,55,42,32,22,19$, and 6-8 kDa (Cornford et al. 1988; Gastaminza et al. 2009). The three species that were used in this experiment showed different band patterns at approximately 17, 30, 80, and $120 \mathrm{kDa}$. This indicates that the three
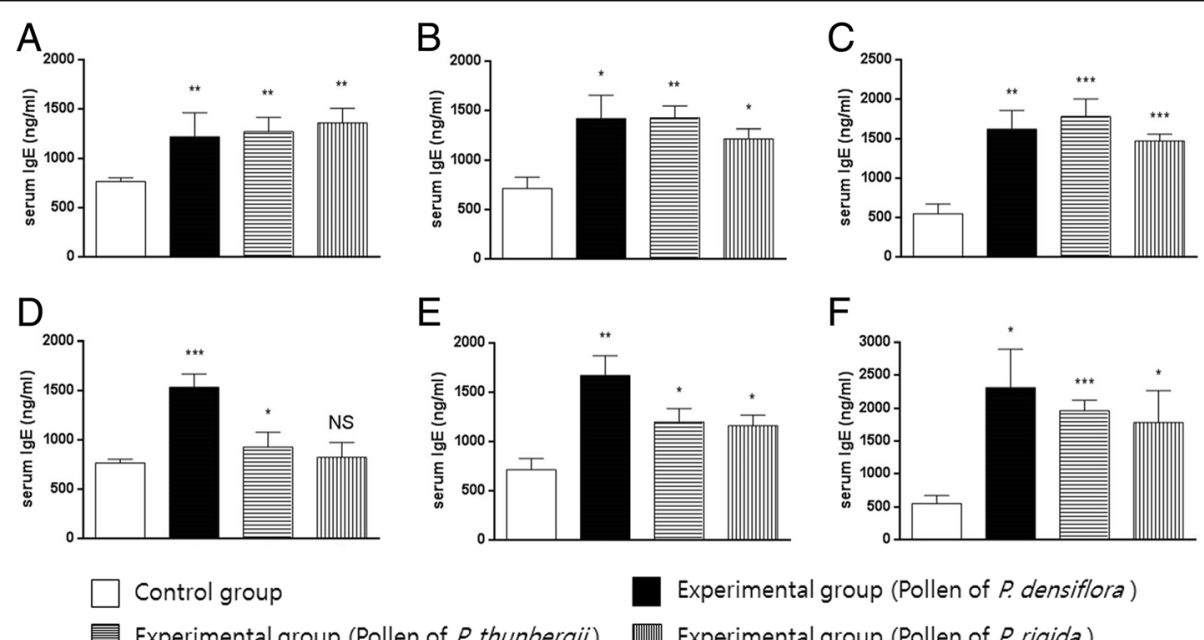

Experimental group (Pollen of $P$. densiffora)

Experimental group (Pollen of $P$. thunbergii)

Experimental group (Pollen of $P$, rigida)

Fig. 6 Analysis of IgE produced in mice after inhalation or skin application of pine pollens. a Day 5, skin. b Day 10, skin. c Day 15, skin. d Day 5 , inhalation. e Day 10, inhalation. f Day 15, inhalation. Statistically significant differences are shown. ${ }^{*} p<0.05,{ }^{* *} p<0.01,{ }^{* * *} p<0.001$ vs control. NS, not significant 
species exhibit differences in antigenicity. It is necessary to identify the region of each of these proteins that acts as an allergen by binding to IgE. Future studies should also identify which protein band patterns cause allergic reactions using sera extracted from patients showing allergic reactions after exposure to pine pollens.

\section{Comparison of IgE induction by pine pollens}

Considering that the dispersion of pine pollens is most intense for about 2 weeks, IgE induction experiments were conducted on mice for 15 days to induce allergic reactions via inhalation and skin application (Tamura 1986; Conford et al. 1990; Maejima et al. 2000; Mahler et al. 2000; Seitzer et al. 2003a, b; Mondoulet et al. 2010, 2012; Tordesillas et al. 2015). Control mice showed no change in the IgE compositions of blood sera collected on days 5,10 , and 15 (Fig. 6). The experimental groups that underwent nasal inhalation and skin tests showed higher levels of IgE than the control group, and these levels increased with the duration of exposure (Fig. 6). In the skin test group, pollen from all three species induced IgE production in mice on the 5th day, and levels increased by similar amounts until the 15th day (Fig. 6a-c). In the nasal inhalation test, mice that inhaled the pollen of $P$. densiflora showed significant increases in IgE production on the 5th and 10th days, but those that inhaled the pollens of the other two species showed only very small increases in IgE production (Fig. 6d, e). However, mice that inhaled each of the three species showed significant increases in IgE production by the 15th day, such that all three groups showed a similar amount of IgE produced by the end of the experiment (Fig. 6f) In addition, on the 15th day, all groups that had inhaled pine pollen exhibited higher IgE levels than those in which pollen was applied to the skin (Fig. 6c, f). Thus, our results indicate that $P$. densiflora, $P$. thunbergii, and $P$. rigida pollen from South Korea can cause allergic reactions in animal models.

\section{Conclusions}

The experimental results demonstrate that the pollens of all three South Korean pine species induce IgE production, and this production was more pronounced when the pollens were inhaled than when they were applied to the skin. Of the three species, the pollen of $P$. densiflora was found to induce the highest level of IgE production.

\footnotetext{
Abbreviations

Ab: Antibody; BCA: Bicinchoninic acid; BSA: Bovine serum albumin; ELISA: Enzyme-linked immunosorbent assay; IgE: Immunoglobulin $\mathrm{E}_{\text {; }}$ P. densiflora: Pinus densiflora; P. rigida: Pinus rigida; P. thunbergii: Pinus thunbergii; PBS: Phosphate-buffered saline; PBS-T: Phosphate-buffered saline Tween 20; SDS: Sodium dodecyl sulfate; SDS-PAGE: Sodium dodecyl sulfate polyacrylamide gel electrophoresis; SPF: Specific pathogen-free; TMB: 3,3',5,5'tetramethylbenzidine; $w / v$ : Weight-to-volume
}

\section{Acknowledgements}

This research was supported by the Environmental Health Center of Ulsan University Hospital of the Ministry of Environment, Korea.

\section{Funding}

This work was supported by the 2016 Research Fund of the University of Ulsan.

Availability of data and materials

Not applicable.

\section{Authors' contributions}

SY conducted the experiments, analyzed the data, and wrote the manuscript. IB participated and designed the research. KR mainly designed the research and revised the paper totally. All authors read and approved the final manuscript.

\section{Ethics approval}

Mouse experimentation was carried out with the approval of the animal experimental ethics committee at the University of Ulsan. (Approval number: KRC-16-010; Title: Study of allergenicity of pine trees pollen: in mice).

\section{Consent for publication}

Not applicable.

\section{Competing interests}

The authors declare that they have no competing interests.

\section{Publisher's Note}

Springer Nature remains neutral with regard to jurisdictional claims in published maps and institutional affiliations.

\section{Author details}

'Department of Biological Science, University of Ulsan, Ulsan 44610, South Korea. ${ }^{2}$ Environmental Health Center, University of Ulsan College of Medicine, Ulsan 44033, South Korea.

Received: 5 April 2017 Accepted: 7 September 2017

Published online: 16 September 2017

\section{References}

Calenoff, E., Beigler, M. A., Friesen, G. L., \& Nichols, J. L. (1990). U.S. patent no. 4,963,356 (pp. 1-30). Washington, DC: U.S. Patent and Trademark Office.

Choi, S. H., Jung, I. Y., Kim, D. Y., Kim, Y. H., Lee, J. H., Oh, I. B., \& Choi, K. R. (2011). Seasonal distribution of airborne pollen in Ulsan, Korea in 2009-2010. Journal of Ecology and Field Biology, 34(4), 371-379.

Choi, S. W., Lee, J. H., Kim, Y. H., Oh, I. B., \& Choi, K. R. (2014). Association between the sensitization rate for inhalant allergens in patients with respiratory allergies and the pollen concentration in Ulsan, Korea. The Korean Journal of Medicine, 86(4), 453-461.

Cornford, C. A., Fountain, D. W., \& Burr, R. G. (1990). IgE-binding proteins from pine (Pinus radiata D. Don) pollen: evidence for cross- reactivity with ryegrass (Lolium perenne). International Archives of Allergy and Immunology, 93, 41-46.

Cornford, C. A., Fountain, D. W., Burr, R. G., \& O'leary, L. (1988). Hayfever in university students (letter). The New Zealand Medical Journal, 101, 520.

Cox, L., Esch, R. E., Corbett, M., Hankin, C., Nelson, M., \& Plunkett, G. (2011). Allergen immunotherapy practice in the United States: guidelines, measures, and outcomes. Annals of Allergy, Asthma \& Immunology, 107, 289-302.

Cox, L., \& Jacobsen, L. (2009). Comparison of allergen immunotherapy practice patterns in the United States and Europe. Annals of Allergy, Asthma \& Immunology, 103, 451-459.

Farnham, J. E. (1988). A new look at conifer allergy (editorial). Allergy and Asthma Proceedings, 9(3), 237-238.

Farnham, J. E., \& Vaida, G. A. (1982). A new look at New England tree pollen. Allergy and Asthma Proceedings, 3(2), 320-326.

Fountain, D. W., \& Cornford, C. A. (1991). Aerobiology and allergenicity of Pinus radiata pollen in New Zealand. Grana, 30, 71-75.

Freeman, G. L. (1993). Pine pollen allergy in northern Arizona. Annals of Allergy, 70(6), 491-494.

Frølund, L., Madsen, F., Gerner Svendsen, U., \& Weeke, B. (1986). Reproducibility of standardized bronchial allergen provocation test. Allergy, 41(1), 30-36. 
Gastaminza, G., Lombardero, M., Bernaola, G., Antepara, I., Munoz, D., Gamboa, P. M., Audicana, M. T., Marcos, C., \& Ansotegui, I. J. (2009). Allergenicity and cross-reactivity of pine pollen. Clinical \& Experimental Allergy, 39, 1438-1446.

Harris, R. M., \& German, D. F. (1985). The incidence of pine pollen reactivity in an allergic atopic population. Annals of Allergy, 55, 678-679.

Hong, C. S. (2015). Pollen allergy plants in Korea. Allergy, Asthma \& Respiratory Disease, 3(4), 239-254.

Howlett, B. J., Vithanage, H. I. M. V., \& Knox, R. B. (1981). Pollen antigens, allergens, and enzymes. Commentaries in plant science, 2(19), 191-207.

Jung, I. Y., \& Choi, K. R. (2013). Relationship between airborne pollen concentrations and meteorological parameters in Ulsan, Korea. Journal of Ecology and Environment, 36(1), 65-71.

Kalliel, J. N., \& Settipane, G. A. (1988). Eastern pine sensitivity in New England. Allergy and Asthma Proceedings, 9(3), 233-235.

Korea forest service. (2011). Statistical yearbook of forest 41 (pp. 32-33).

Lawrence, G. H. (1951). Taxonomy of vascular plants. New York: Macmillan.

Maejima, A., Tamura, K., Taniguchi, Y., \& Saito, S. (2000). Study on the inhalation exposure conditions of pollen for inducing the production of Japanese cedar (Cryptomeria Japonica) pollen-specific IgE antibody in mice. Jpn J. Palynol, 46(2), 155-161.

Mahler, V., Diepgen, T. L., KuB, O., Leakakos, T., Truscott, W., Schuler, G., Kraft, D., \& Valenta, R. (2000). Mutual boosting effects of sensitization with timothy grass pollen and latex glove extract on IgE antibody responses in a louse model. The Journal of Investigative Dermatology, 114(5), 1039-1043.

Mondoulet, L., Dioszeghy, V., Ligouis, M., Dhelft, V., Dupont, C., \& Benhamou, P. H. (2010). Epicutaneous immunotherapy on intact skin using a new delivery system in a murine model of allergy. Clinical \& Experimental Allergy, 40(4), 659-667.

Mondoulet, L., Dioszeghy, V., Ligouis, M., Dhelft, V., Puteaux, E., Dupont, C., \& Benhamou, P. H. (2012). Epicutaneous immunotherapy compared with sublingual immunotherapy in mice sensitized to pollen (Phleum pratense). International Scholarly Research Network Allergy, 2012, 1-8.

Newmark, F. M., \& Itkin, I. H. (1967). Asthma due to pine pollen. Annals of Allergy, $25,251-252$

Oh, J. W., Lee, H. R., Kim, J. S., Lee, K. I., Kang, Y. J., Kim, S. W., Kook, M. H., Kang, H. Y., Kim, J. S., Lee, M. H., Lee, H. B., Kim, K. E., Pyun, B. Y., Lee, S. I., \& Han, M. J. (2000). Aerobiological study of pollen and mold in the 10 states of Korea. Pediatric Allergy And Respiratory Disease, 10, 22-33.

Park, J. W., Ko, S. H., Kim, C. W., Jeoung, B. J., \& Hong, C. S. (1999). Identification and characterization of the major allergen of the Humulus japonicus pollen. Clinical \& Experimental Allergy, 29(8), 1080-1086.

Pettyjohn, M. E., \& Levetin, E. (1997). A comparative biochemical study of conifer pollen allergens. Aerobiologia, 13, 259-267.

Rowe, A. H. (1939). Pine pollen allergy. Journal of Allergy, 10, 377-378.

Seitzer, U., Bussler, H., Kullmann, B., Petersen, A., Becker, W. M., \& Ahmed, J. (2003a). Characterization of immunoglobulin $\mathrm{E}$ responses in Balb/c mice against the major allergens of timothy grass (Phleum pratense) pollen. Clinical \& Experimental Allergy, 33(5), 669-675.

Seitzer, U., Bussler, H., Kullmann, B., Petersen, A., Becker, W. M., \& Ahmed, J. (2003b). Quantitative assessment of immediate cutaneous hypersensitivity in a mouse model exhibiting an IgE response to Timothy grass allergens. Medical Science Monitor, 9(12), BR407-BR412.

Shahali, Y., Majd, A., Pourpak,Z., Tajadod G., Haftlang, M., \& Moin, M. (2007). Comparative study of the pollen protein contents in two major varieties of Cupressus arizonica planted in Tehran. Iranian journal of allergy, asthma and immunology, 6(3), 123-127.

Tamura, S., Kobayashi, T., Kikuta, K., Nakagawa, M., Sakaguchi, M., \& Inouye, S. (1986). IgE antibody responses against Japanese cedar pollen in the mouse. Microbiology and Immunology, 30(9), 883-891.

Tordesillas, L., Goswami, R., Benedé, S., Grishina, G., Dunkin, D., Järvinen, K. M., Maleki, S. J., Sampson, H. A., \& Berin, M. C. (2015). Skin exposure promotes a Th2-dependent sensitization to peanut allergens. The Journal of Clinical Investigation, 124, 4965-4975.

Walker, I. C. (1921). Frequent causes and the treatment of seasonal hay-fever. Archives of Internal Medicine, 28, 71-118.

Weber, R. W. (2005). Cross-reactivity of pollen allergens: recommendations for immunotherapy vaccines. Current opinion in allergy \& clinical immunology, $5(6), 563-569$.

\section{Submit your next manuscript to BioMed Central and we will help you at every step:}

- We accept pre-submission inquiries

- Our selector tool helps you to find the most relevant journal

- We provide round the clock customer support

- Convenient online submission

- Thorough peer review

- Inclusion in PubMed and all major indexing services

- Maximum visibility for your research

Submit your manuscript at www.biomedcentral.com/submit

) Biomed Central 